\title{
Między ratio a emotum. Polsko-rosyjskie postrzeganie wzajemne w perspektywie binarnej
}

\section{Between ratio and emotum. Polish-Russian mutual perception in a binary perspective}

\begin{abstract}
A characteristic feature of Polish-Russian mutual perception is binarity, manifesting itself in various discursive spaces, from colloquial stereotypes, through popular literature, to sophisticated forms of meta-historical discourse. Asian-Europeanness, Latin-Byzantism/Orthodoxy, collectivism-individualism, and authenticity-falsehood, are just some of the oppositions that organise the social imagination of Poles and Russians in the sphere of their mutual assessments and opinions. The article draws attention to the partial manifestations of such oppositions (literary discourse, postcolonial studies, etc.) in order to show their hidden, dialectical dimension. To achieve this goal, the author refers to the category of ratio and emotum, which refers to a specific current of the European philosophical tradition. Both of these binary categories are the foundation for creating an image of the Other. They also fit into self-defining strategies important for understanding Polish and Russian identity.
\end{abstract}

Keywords: rationality, binarity, stereotypes, literature, postcolonial studies, Poland, Russia

Tomasz Nakoneczny, Uniwersytet im. Adama Mickiewicza w Poznaniu, Poznań - Polska, tomasz. nakoneczny@wp.pl, tomnak@amu.edu.pl, ORCID ID: https://orcid.org/0000-0002-4241-7862

Upadek komunizmu otworzył nową perspektywę refleksji nad stosunkami polsko-rosyjskimi. Od razu przy tym ujawniły się jej cechy charakterystyczne, znane dobrze z przeszłości. Najbardziej bodaj trwałym z tych walorów pozostaje binarność, przejawiająca się w licznych przeciwstawieniach dokonywanych na wielu płaszczyznach identyfikacji i wzajemnych odniesień: tożsamościowej (Polak katolik - Rosjanin prawosławny), politycznej (polskie umiłowanie wolności - rosyjski despotyzm), historycznej (Rzeczpospolita szlachecka - imperium carskie), by wymienić tylko kilka wybranych.

Binarność ta określiła w przemożnym stopniu model wzajemnej percepcji kulturowej Polaków i Rosjan. W skrajnej postaci wyraża się ona w przeświadczeniu o fundamentalnej „niezgodności kulturowej” między Polakami i Rosjanami, 
co prowadzi, jak zauważa Andrzej Kępiński, do kategorycznej negacji wszystkich wartości sąsiada.

Rosję wyłącza się poza obręb kultury europejskiej, jest to bowiem „Północ”, przy czym owa „Północ” nie jest pojęciem geograficznym, lecz stanowi epitet waloryzacyjny, oznaczający krainę obcą, daleką - synonim zła, wrogości, szatana. Podobnie jak we współczesnym języku potocznym określenie „Syberia” (Kępiński 155).

Ukształtowane na tej podstawie stereotypy i narracje okazują się wyjątkowo odporne na rewizje. Ci, którzy zastanawiają się nad możliwością znalezienia płaszczyzny dialogu między oboma narodami, wolnej od stygmatyzujących rozróżnień, muszą wcześniej czy później zmierzyć się z pytaniem o referencjalność polsko-rosyjskich przedstawień. Czyli o to, w jakiej mierze stanowią one odzwierciedlenie uwarunkowań pozasymbolicznych. Formuła „odnowionego widzenia świata” wzięta z zasobów frazeologicznych rosyjskiego formalizmu, zakładająca możliwość zmiany obrazu zjawiska poprzez zmianę języka jego opisu, nie mogłaby okazać się w danym przypadku użyteczna w wymiarze ogólnospołecznym, m.in. dlatego, że dotychczasowy model binarny wspierają mniej czy bardziej otwarcie dyskursy władzy instytucjonalnej. W nie mniejszym stopniu niż karmiona mitami wyobraźnia zbiorowa. Ujmując rzecz w perspektywie semiotycznej, mamy podstawy sądzić, że nieodparta moc binarności, o której mowa w artykule, wynika w znacznej mierze z samej natury projekcji mityzacyjnych. Natomiast społeczną nośność i sugestywność tych ostatnich powinniśmy wiązać z wielokrotnie podnoszoną przez semiotyków zdolnością mitu do niepostrzeżonego przenikania do języka potocznego.

Opozycyjna wobec działań mitologa, a zatem wobec demistyfikacji mitu, jest naturalizacja mitu, która wydarza się przy bezkrytycznym jego przyjmowaniu, szczególnie przy przekształceniu mitu $-\mathrm{z}$ przedmiotu wiary $-\mathrm{w}$ przedmiot wiedzy prawomocnej. Naturalizacja mitu to przyjmowanie znaku mitycznego wraz z jego znaczeniem, czyli pojęciem maksymalnie ujednoznacznionym, za źródło wiedzy niepodlegającej namysłowi, a tym bardziej wątpieniu czy krytyce (Gołębiewska 84).

Naturalizacja obrazu Rosji jako państwa wrogiego/niebezpiecznego per se, obrazu głęboko zinternalizowanego przecież nie tylko w głównym nurcie polskiego dyskursu niepodległościowego, czyni dziś właściwie niemożliwym łączenie polskiej racji stanu z jawnie deklarowaną i rzeczowo uzasadnianą „opcją rosyjską". W każdym razie niemożliwym bez narażania na posądzenie o zdradę narodowych interesów. Andrzej Skrzypek zwraca w tym kontekście uwagę na istnienie wśród polskiej opinii publicznej dogmatycznego przekonania, „że interesy państwowe Rosji, jaka by ona nie była, zawsze muszą się zwracać przeciwko niepodległości Polski, a prawdziwy patriota nie może stawiać sobie za cel jakiekolwiek porozumienie z Moskwą" (Skrzypek 78). 
Warto jednak od razu zauważyć, że w perspektywie rozważań kulturalistycznych poszukiwanie „realnych uwarunkowań” wiedzie w istocie do odkrywania kulturowych przesłanek tych uwarunkowań, czyli do swoistej tautologii. Pytanie zatem musi zostać sformułowane precyzyjniej. Ci, którzy chcieliby dotrzeć do źródeł rosyjskiego/polskiego stereotypu poprzez identyfikację określonych związków przyczynowo-skutkowych zachodzących między szeroko pojętą sferą społecznej praxis a jej symboliczną ekspresją, byliby w nie lepszej sytuacji niż ci, którzy charakterystykę bezpośrednich polsko-rosyjskich relacji (gospodarczych, politycznych, instytucjonalnych etc.) pragnęliby tworzyć na bazie odwołań do kulturalistycznie rozumianej ramy percepcyjnej. Obie te sfery, symboliczna i praktyczna, warunkują się wzajemnie, co utrudnia, a w przypadku zjawisk zanurzonych głęboko w historii niekiedy wręcz uniemożliwia, ustalanie wektorów „wpływów” między nimi. Pozostając na gruncie założeń kulturalistycznych, można jednak pokusić się o uchwycenie $\mathrm{w}$ danym zespole symbolicznych przedstawień sygnałów pozwalających je „urealnić”, to znaczy: a) ujawnić mechanizmy ich (samo)uzasadniania/(auto)racjonalizacji; b) wykazać interferencje z tymi obszarami rzeczywistości społecznej, z którymi są te przedstawienia dyskursywnie powiązane, a które nie zawsze się w nich bezpośrednio uobecniają, choć mają - za sprawą zauważonych interferencji - wpływ na ich kształt i zawartość.

Chciałbym w ramach przyjętej strategii eksplanacyjnej odwołać się do dobrze zadomowionego w kulturze europejskiej (zwłaszcza filozoficznej i religijnej) przeciwstawienia ratio i emotum, które osadzone jest na podobnej strukturze binarnej co polsko-rosyjskie stereotypy wzajemne. Odniesieniem dla pierwszej kategorii jest zbiór postaw życiowych/form konceptualizacji, które wyróżnia afirmacja spójnych, celowych i zrównoważonych obrazów rzeczywistości, opartych na świadomie przyjmowanych i traktowanych jako uniwersalne/obiektywne kryteriach/racjach. Pogłębiony, historyczny przegląd kategorii rozumu ludzkiego (ratio) i racjonalności (rationalitas) proponuje Edmund Morawiec. W kontekście niniejszych rozważań szczególnie użyteczne okazują się konstatacje badacza dotyczące pojęcia racjonalności:

Takie znaczenie słowa „racjonalność” koheruje ze znaczeniem łacińskiego słowa rationalitas, które znaczy tyle, ile proporcja, miara, związek i oznacza „organizację” tego, czego dotyczy. Zakłada ona wielość elementów w przedmiocie, w którym występuje jako własność. Racjonalność będzie wyrażać się więc w układzie tych elementów, w stosunkach wiążących te elementy w pewną całość, czyli inaczej mówiąc, w strukturze całości, niezależnie od tego, czym ta całość jest. Tak więc pojęta racjonalność będzie się sprowadzać do organizacji całości, dzięki której daje się ją wyodrębnić z innych całości niezależnie od tego, czym by ta całość była, czy przedmiotem naturalnym, czy przedmiotem kulturowym, procesem poznawczym, czy jego rezultatem, czy też jakimś innym typem ludzkiego działania lub jego rezultatem. Racjonalność danego przedmiotu będzie się wyrażać w jego określoności i wewnętrznej niesprzeczności, w posiadaniu racji tego, że jest, i tego, że jest tym, a nie innym przedmiotem (Morawiec 157). 
Z kolei sferę emotum można odnieść do postaw/form konceptualizacji, którym przypisywane są braki w zakresie wymienionych przymiotów i które $\mathrm{z}$ tego powodu cechuje - faktyczna bądź mniemana - niespójność, niecelowość, nieciągłość etc. Przynależność do ratio traktowana jest jako synonim wyższego statusu poznawczego, co wypada wiązać z filozoficzną, a ściślej platońską, filiacją tej kategorii. Z kulturalistycznego punktu widzenia ważniejszy jest tu jednak wymiar psychologiczny: identyfikacja z ratio daje poczucie przewagi nad tymi, którzy pozostają w domenie emotum. Istotne jest również to, że podmiotem rozróżnień obu sfer jest ten, kto utożsamia się z ratio. Emotum to swoista projekcja ratio.

Zaznaczająca się w niektórych okresach ewolucji kulturowej silniej opozycja ratio i emotum formułowana jest na zasadzie binarności (np. racjonalność męska vs. irracjonalność kobieca, ład cywilizacji vs. dzikość barbarii etc.), w czym wolno widzieć czynnik maskujący rozliczne niedogodności psychologiczne będące efektem wzajemnych konfrontacji. Binarność ta odgrywa również kluczową rolę w procesie wytyczania jednoznacznych granic między My i Oni (Swoi - Obcy). Wszystko to powinno budzić czujność badawczą kulturalisty, ponieważ tak rozumiana binarność może skrywać dialektyczne związki zachodzące między przeciwstawnymi członami opozycji. Tak właśnie dzieje się w przypadku wzajemnego polsko-rosyjskiego postrzegania. Na zjawisko to zwraca pośrednio uwagę Przemysław Czapliński, gdy pisze o mapowaniu mentalnym wschodniego sąsiada:

Im bardziej jednak Rosja w piśmiennictwie polskim funkcjonuje jako suma wszystkich obcości, tym mocniej staje się treścią głęboko intymną. [...] Z jednej strony jest ona osobnym światem, niemającym żadnych punktów stycznych z Polską: tam Azja, tu Europa, tam autorytaryzm, tu demokracja, tam dzikość, tu cywilizacja. $Z$ drugiej strony jako układ odniesienia, bez którego nie jesteśmy w stanie siebie zdefiniować, określić własnej przyszłości i wyznaczyć miejsca w Europie, Rosja przestaje być osobnym państwem i obcą kulturą, a nawet realnym obszarem zamieszkiwanym przez prawdziwych ludzi, staje się natomiast zbiorem fantazmatów, rojeń, życzeń i lęków (Czapliński 14).

Niniejszy artykuł proponuje spojrzenie na binarny wymiar polsko-rosyjskich wzajemnych odniesień jako na wymiar maskujący dialektyczne zależności występujące na płaszczyźnie modelowania polskiego i rosyjskiego Innego. Modelowanie to nie przebiega zasadniczo według procedur orientalizacyjnych: obaj aktorzy wiedzą o sobie zbyt wiele, by uproszczenia wzajemnych wizerunków wiązać raczej z nieuwagą czy brakiem odpowiednich języków opisu niż ze złą wiarą bądź nieczystym sumieniem. Dlatego m.in. opozycja ratio - emotum wydaje mi się bardziej adekwatna. Charakter wspomnianych zależności wyznacza waga, jaką mają dla siebie oba podmioty w sferze autodefinicyjnej. Artykuł postuluje również rewizję - zwłaszcza po stronie polskiej - jednostronnie uformowanej matrycy pojęciowej, na podstawie której kształtowany jest od co najmniej 
dwóch stuleci obraz sąsiada. Jednostronność ta wynika z dominacji czynnika literaturoznawczego, a szerzej - ze swoistej fetyszyzacji kategorii kulturowych jako narzędzi definiowania rosyjskiego Obcego i własnego względem niego usytuowania. Przyjętą perspektywą oglądu tematu jest perspektywa polska, jakkolwiek nieuchronne - choć wybiórcze z uwagi na ekonomię wywodu - okażą się odwołania do percepcji rosyjskiej.

\section{1.}

Wspomnianej binaryzacji towarzyszy frapujący paradoks. Oto wśród krajów, z którymi mieli Polacy w historii relacje więcej niż zdawkowe, trudno w istocie znaleźć przykład takiego, którego obraz byłby równie ambiwalentny, co obraz Rosji. Ten ostatni podlega bowiem w optyce polskiej rozszczepieniu na dwie tonacje barw: ciemną, związaną z wyobrażeniem rosyjskiej historii i państwowości (Rosja jako uosobienie autorytaryzmu, żądny cudzych ziem imperialista, wschodnie barbaricum etc.) oraz jasną, towarzyszącą na ogół wizerunkowi rosyjskiej kultury artystycznej (zauważalna wśród polskich elit admiracja dla rosyjskiej literatury, muzyki oraz sztuki, zwłaszcza przedrewolucyjnej). Kultury jednocześnie - warto zauważyć - umieszczanej od pewnego czasu w polu obserwacyjnym dyskursów podejrzeń, od krytyki feministycznej do studiów postkolonialnych. Wynikłe stąd dla niej niedogodności - już to psychologicznej, już to etycznej natury - nie dają się wythumaczyć samym tylko faktem próby redefiniowania idiomu rosyjskiego d'une manière critique; kultura rosyjska wykazywała bowiem dotąd niejednokrotnie znaczny krytycyzm, a nawet autoironię (Piotr Czaadajew, Lew Tołstoj, Wiktor Jerofiejew, Wiktor Pielewin etc.). Daleko ważniejsze wydaje się ukierunkowanie wspomnianych dyskursów na demaskację tych elementów konstruktu tożsamościowego (niedomówień, pęknięć, niespójności etc.), które w sposób zasadniczy naruszają jego etyczną wiarygodność, a tym samym kulturową atrakcyjność. Tendencję tę wzmacniają opinie autorytetów dyskursu prawicowo-konserwatywnego, w tym zwłaszcza Ewy Thompson, znanej i wpływowej w Polsce badaczki postkolonialnej.

Niektórzy zachodni komentatorzy wyrażali podziw dla rosyjskich obyczajów i sposobów postępowania, nie zwracając uwagi na fakt, że temu, co czyni je tak urokliwymi i poruszającymi - w porównaniu ze zwyczajami zachodnimi - przeważnie towarzyszą cechy, których z racjonalnego i empirycznego punktu widzenia żaden czar nie może usprawiedliwić. Wpisane w rosyjską kulturę poszukiwanie duchowej mądrości, gotowość do wyrzeczeń i uczenia się, przywiązanie do tradycji oraz czystość celów łączą się z odmową poznawania rzeczy niewygodnych dla siebie, brakiem poczucia społecznej spójności oraz zmysłu tradycji, milczącą akceptacją konceptu, że jednostka jest bezbronna względem państwa, oraz gotowością do wyszydzania wczorajszych bohaterów (Thompson 2019: 370-371). 
Zgodnie z najbardziej bodaj widoczną dziś w polskiej krytycznej hermeneutyce wykładnią wyróżniająca kulturę rosyjską (w szczególności wysoką) zdolność do afirmowania własnej idiosynkratyczności okazuje się w ostatecznym rozrachunku formą mimikry, czynnikiem maskującym jej polityczne uwikłania jako nieuchronnie zdeterminowane przez historyczną specyfikę Rosji. „Obecna fascynacja literaturą i kulturą rosyjską - stwierdza Dariusz Skórczewski - jest tyleż pochodną jej immanentnej wartości, co efektem hegemonistycznej pozycji ZSRR i Rosji jako światowego imperium" (Skórczewski 2007: 4). Znacznie ograniczona została możliwość odczytywania jej ukrytych wzorów w planie czysto estetycznym bądź egzystencjalnym. Lektura w tym trybie zaczęła rodzić różnego rodzaju podejrzenia (o serwilizm, interesowność, naiwność etc.) i domagać się uzasadnień/usprawiedliwień. Skórczewski zwraca uwagę na zjawisko „niewymuszonej akceptacji”, a nawet entuzjazmu przejawianego przez polską elitę w stosunku do oferty „autoryzowanej przez [rosyjskiego - przyp. T.N.] hegemona”. Pisząc w tym kontekście o kompradorskich postawach elit peerelowskich, tak widzi wspomniany mechanizm samousprawiedliwień:

Czy bowiem urodzonym w niewoli przystawało darzyć atencją kulturę znienawidzonego, pogardzanego i wywołującego trwogę hegemona? Jeśli kwestia ta w ogóle budziła refleksję, to dla własnego entuzjazmu, fascynacji czy po prostu zainteresowania poszukiwano zazwyczaj uzasadnień antropologicznych (,inna Rosja”, „Rosjanie, nie Sowieci”), estetycznych (,piękny język rosyjski”, ,wielka rosyjska literatura” [...] lub moralnych (na ich nienawiść odpowiemy chrześcijańską miłością) (Skórczewski 2016: 61).

Dla przywołanej wyżej Thompson, atrakcyjna - zwłaszcza w percepcji elit zachodnich - ,nieuchwytność” Rosji jawi się jako specyficzny aspekt jej imperializmu. Tak cenioną w Polsce, niezależnie od politycznych konstelacji, literaturę rosyjską ukazuje autorka Trubadurów imperium przez pryzmat jej służebnej relacji z rosyjskim projektem imperialnym. „Interpretując rosyjskie teksty literackie jako zasadniczo wolne od zaangażowania w militarną postawę Rosji, komentatorzy rosyjscy i zachodni ulegają spektakularnej zdolności tych tekstów do unikania spojrzenia krytyka, które mogłoby odsłonić ich usługi na rzecz imperium" (Thompson 2000: 49-50).

Znaczenie zarysowanego tu tylko szkicowo nurtu „hermeneutyki podejrzeń” wzmacniane jest przez współczesny dyskurs literacki, zwłaszcza w jego reportersko-eseistycznej odmianie. Warto w tym kontekście przywołać Ryszarda Kapuścińskiego jako autora Imperium oraz Krystynę Kurczab-Redlich jako autorkę Pandrioszki oraz Glowa o mur Kremla, których relacje dotyczące poradzieckiej Rosji Joanna Jastrzębska umieszcza w kręgu zjawisk określonych przez nią jako „symboliczna zemsta interpretacyjna” (Jastrzębska 69). Zemsta wpisująca się w szerszy, społeczno-polityczny zakres rozliczeń z dawnym/niedawnym hegemo- 
nem, co w danym przypadku wiąże się z uruchomieniem arsenału środków narracyjnych, które współczesna humanistyka rozpoznaje jako praktyki orientalizujące. Ich efektem pozostaje endemiczna w polskiej kulturze wysokiej egzotyzacja rosyjskiego sąsiada. Zarówno Kapuściński, jak i Kurczab-Redlich odwołują się do głęboko zinternalizowanego w polskim myśleniu o Rosji paradygmatu symbolicznego, którego główną konstantą wydaje się przeświadczenie o pozaeuropejskim - cywilizacyjnie i kulturowo - usytuowaniu Rosji i o równoległym silnym polskim - niezależnie od okoliczności zewnętrznych (zabory, komunizm etc.) zakorzenieniu w europejskości. Co ciekawe, Czapliński dostrzega w narracji Kapuścińskiego oznaki nie tyle orientalizacji, ile tercjalizacji Rosji, czyli uwypuklania takich cech rzeczywistości rosyjskiej, które upodabniają ją lub zgoła zlewają z rozpowszechnionym obrazem Trzeciego Świata (równie ważne jest tu nastawienie, jakie przyjmuje względem tej rzeczywistości podmiot opisujący, a więc sam Kapuściński). Zgadzając się z obserwacją Czaplińskiego, można w tym widzieć swoiste „przekroczenie” dotychczasowych standardów orientalizacyjnych, które zdaje się uzasadniać właściwa mu celowość. Poznański badacz utożsamia tę ostatnią z chęcią zamaskowania kłopotliwego położenia Polski i jej kultury, w jakim postawiła je rekonfiguracja społeczna i polityczna spowodowana przez rozpad ZSRR. Zdaniem Czaplińskiego, autor Imperium, powtarzając spojrzenie z zachodniej perspektywy i „zakrywając” przy tym Polskę, przesunął swój kraj niepostrzeżenie ku Zachodowi, sugerując w ten sposób, że „Polska, o której się nie mówi, należy do kultury, w której imieniu przemawia autor" (Czapliński 37).

Subtelne, acz sugestywne transpozycje semantyczne, z jakimi mamy do czynienia u Kapuścińskiego, oraz poetyka kontrastów, eksponująca rosyjskie braki „utwierdzające” polską wyższość, charakterystyczna dla relacji Kurczab-Redlich, to przykłady literackich „uzupełnień” w stosunku do strategii dyskursu krytycznego. W obu tych obszarach piśmienniczych mamy do czynienia $\mathrm{z}$ demaskacją pozorności rosyjskich autoprzedstawień (imperialny splendor wzmacniany przez atrakcyjność kultury wysokiej, wpisywalność w europejskie kategorie kulturowo-cywilizacyjne, wewnętrzna integralność, reprezentatywność w stosunku do całego obszaru imperium etc.). Latentnym wymiarem tej demaskacji pozostaje na ogół założenie o fundamentalnej nieprzystawalności kultury polskiej i rosyjskiej, któremu towarzyszy - nie zawsze uzewnętrzniane, a być może i nie zawsze uświadamiane - przeświadczenie o polskiej wyższości. Znaczenie, jakie w podważaniu statusu Rosji mają owe ukryte założenia, jest kluczowe dla uchwycenia natury binarności w polskich obrazach współczesnej (a jednocześnie historycznej) Rosji. Binarność ta pozwala bowiem ukryć kwestie niewygodne, których potencjalna lista jest dość długa. Jedną z nich może być np. pytanie o przyczyny rosyjskiej skuteczności w narzucaniu korzystnych autoprzedstawień i polskiej w tym zakresie słabości. Wypada więc zgodzić się 
z przywołaną wcześniej tezą Czaplińskiego. Rosja nie jest bynajmniej „ciałem obcym" w polskim systemie autopostrzegania, odgrywa w nim rolę czynnika (współ)definiującego polską specyfikę i polskie miejsce w świecie. Przede wszystkim jako radykalne uosobienie Wschodu pozwala wytyczyć międzycywilizacyjną linię podziału, limitując w ten sposób polską nieokreśloność (środkowo-wschodniość?) i peryferyjność wobec Zachodu. Ma to rozliczne reperkusje psychologiczne. Jak zauważa Maria Janion, „kompleks polskiej wtórności wobec Zachodu wyładowuje się w przekonaniu, że Ruski są jeszcze wtórniejsi i jeszcze gorsi od nas" (Janion 262).

Spychanie Rosji do sfery emotum (nieciągłości, niekonsekwencji, niekoherencji, lokalnej partykularności etc.) i paralelne samoutwierdzanie swojej przynależności do sfery ratio (uniwersalnej cywilizacji Zachodu, koherencji, porządku, praworządności etc.) to jedna $\mathrm{z}$ dwóch płaszczyzn, na których ujawnia się binarność polskiego punktu widzenia (jego odwrotnością jest rosyjski, do którego jeszcze nawiążemy). Nazwijmy ją epistemologiczną, jako że wyraża się ona w ramach określonej percepcji kulturowej. Druga płaszczyzna wyłoni się wówczas, gdy tę pierwszą, epistemologiczną, zechcemy ujrzeć na szerszym, wielodyskursywnym tle. Takiej poszerzonej optyce sprzyja wydatnie włączanie od pewnego czasu do polskiej debaty tożsamościowej dyskursu geopolitycznego (Jacek Bartosiak, Leszek Sykulski, Instytut Geopolityki, Nowa Konfederacja i wiele innych podmiotów) ukierunkowanego na obiektywizację obrazu relacji polsko-rosyjskich opartych na uwzględnianiu czynników geograficznych, wojskowych, geostrategicznych czy ekonomicznych (zasoby). W tej perspektywie „emotywizacja” wizerunku Rosji, z jaką mamy do czynienia w dyskursie kulturalistycznym oraz literackim, musi okazać się strategią wysoce niezadowalającą poznawczo. Geopolitycy zupełnie inaczej niż kulturaliści opisują m.in. zmienne charakteryzujące rosyjską politykę wewnętrzną (centralizacja władzy) i międzynarodową (praktyki imperialne).

Geografia powoduje że Rosja musi mieć silny rząd centralny i centralnie sterowany system gospodarczy, inaczej ma tendencję do rozpadu. Zatem Federacja Rosyjska, żeby zapobiec rozpadowi, musi rozwiązać dwa problemy geopolityczne: utrzymanie imperium oraz utrzymanie bezpieczeństwa wewnętrznego. Jednocześnie realizacja jednego celu zagraża utrzymaniu drugiego (Bartosiak 228).

Mamy tu zatem do czynienia z interesującą zmianą wektorów: tradycyjny polski punkt widzenia, mocno osadzony w paradygmacie literaturocentrycznym i w zbiorowej aksjologii, zostanie przemieszczony do sfery emotum, której przeciwstawia się sferę realpolitik opisywaną w kategoriach racjonalności, interesów, potencjałów oraz redukcji - w wymiarze zarówno konceptualnym, jak i operacyjnym - czynników emotywnych oraz moralno-etycznych. 
Zauważona ambiwalencja nie jest $\mathrm{w}$ istocie sprzeczna $\mathrm{z}$ binarną kategorycznością. Jeśli pierwsza różnicuje negatywny obraz Innego w duchu uznania dla jego przymiotów, a druga równolegle upraszcza go dla zamaskowania niewygodnych zależności, może rodzić się podejrzenie, że źródła tych niekonsekwencji nie znajdują się w sferze idiosynkratyczności. Istotnie, ewolucja polsko-rosyjskich projekcji wzajemnych przebiega frapująco zgodnie z krzywą napięć i konfliktów politycznych, których podstawą wydaje się geopolityka z charakterystyczną dla niej interesownością i pragmatyzmem.

Po stronie rosyjskiej świadomość tego stanu rzeczy artykułowana jest już na wczesnym etapie konsolidacji imperium, w Historii państwa rosyjskiego (История государства Российского, 1816-1829) Nikołaja Karamzina. Jak zauważa Andrzej Nowak, dzieło Karamzina uczyło współczesnych mu Rosjan, że „polskie państwo zawsze było wrogiem ich ojczyzny”, a „ziemie, które Rosja uzyskała w trzech rozbiorach, były faktycznie polsko-litewskim zaborem, stanowiącym właściwie odwieczną dziedzinę «ruską»”. Wolno widzieć we wpływowej wśród XIX-wiecznej inteligencji rosyjskiej Karamzinowskiej wykładni dziejów „rzutowaną w przeszłość, lecz wyprowadzoną ze współczesnej «troski obywatela rosyjskiego» wielką przestrogę przed jakimikolwiek ustępstwami wobec Polaków" (Nowak 63). Dzieło Karamzina nie tylko zwiastowało etap ugruntowywania władzy imperialnej nad ziemiami świeżo podbitego państwa polsko-litewskiego, ale też podnosiło wagę geopolityczną „czynnika polskiego” w kontekście definiowania kluczowych interesów imperialnych Rosji.

Zwraca w tym kontekście uwagę charakterystyczna repetytywność postaw ukształtowanych w zmiennych politycznie warunkach zaborów. Po stronie rosyjskiej archetypicznym fenomenem pozostaje w tej mierze postawa życzliwego początkowo Polakom Michaiła Katkowa, którego antypolska publicystyka zrodzona przez nabrzmiewający od końca lat 50. XIX wieku konflikt społeczno-narodowościowy, kulminujący w wybuchu powstania styczniowego, weszła do kanonu rosyjskiej myśli nacjonalistycznej. Współcześnie w ten krąg postaw wpisują się - toutes proportions gardées - wypowiedzi Władimira Żyrynowskiego, z właściwym sobie woluntaryzmem na przemian dyskredytującego i ,dowartościowującego" Polskę i Polaków, a po części również Aleksandra Dugina.

Co znamienne, trwałością wykazują się również ukształtowane w okresie zaborów „,chwyty” imagologiczne w sferze prezentacji Innego, i to po obu stronach. Rafał Ziemkiewicz, pisząc o katastrofie smoleńskiej, podnosi wobec strony rosyjskiej zarzuty przypominające te, którymi w latach 60. XIX wieku posługiwała się prasa rosyjska zarzucająca polskim „buntownikom” irracjonalność i kierowanie się opacznie rozumianymi zasadami honoru. 
Wbrew przyjętemu przez Tuska założeniu polityka rosyjska nie jest racjonalna, ale emocjonalna. Przyznanie się do choć najdrobniejszego uchybienia po swej stronie dla szurniętych na punkcie swego dziwacznie pojmowanego „honoru” Rosjan byłoby niedopuszczalnym sponiewieraniem godności ich wielkiego narodu. Więc wolą brnąć w najbardziej nawet idiotyczne kłamstwa, upierać się, że Tupolew z prezydentem na pokładzie spadł, bo zderzył się z innym, nieznanym samolotem amerykańskiej konstrukcji, jawnie niszczyć albo ukrywać dowody, bo święty honor Rosji jest taki, że przyznać się nie wolno do niczego, nawet do niedopiętego guzika u lejtnanta (Ziemkiewicz, źródło elektroniczne).

Polityczne uwarunkowania polsko-rosyjskich uprzedzeń dostrzega i wnikliwie opisuje Aleksander Lipatow. „Kontakty bezpośrednie w sferze kultury - zauważa rosyjski uczony - ciągle łączyły Rosjan z Polakami, sprzyjając lepszemu ich rozumieniu. Równocześnie polityka oficjalna ciągle ich dzieliła i rozłączała" (Lipatow 2000: 251). Lipatow zwraca uwagę na istnienie dwóch różnych sfer społecznych kształtujących na przestrzeni ostatnich dwóch stuleci wizerunek Polski i Polaków - „rosyjskiego społeczeństwa obywatelskiego” i „rosyjskiego społeczeństwa państwowego". Pierwsze z nich przyswajało polskość przez filtr kulturowy, dzięki czemu kultura polska była odbierana „w jej przejawach wewnętrznych, czyli w jej istocie, poprzez zrozumienie innej mentalności narodowej" (Lipatow 2000: 251). Odbiór taki był i ,pozostaje niemożliwy, bo niezrozumiały” dla rosyjskiego społeczeństwa państwowego ze względu „na istotę takiego społeczeństwa, historycznie ukształtowanego i nadal współodtwarzanego przez system rządzenia oraz wytyczaną przezeń politykę wewnętrzną i zewnętrzną" (Lipatow 2000: 251). Zdaniem Lipatowa sytuacja skomplikowała się w okresie zaborów, kiedy Polska stała się częścią państwa rosyjskiego, a Polacy zaczęli być zmuszani do przyjmowania reguł i wartości rosyjskiego społeczeństwa państwowego, które postrzegali jako obce, a nawet odpychające. „Ów brak chęci Polaków do życia zgodnie z wymaganiami rosyjskiej państwowości i rosyjskiej mentalności wywoływał w społeczeństwie państwowym irytację" (Lipatow 2000: 251). Tę irytację wzmacniała niewątpliwie problematyczność Polski jako potencjalnego sprzymierzeńca (geo) politycznego, co widać wyraziście na przykładzie dyskursu panslawistycznego. Jego rdzeniem był geopolityczny koncept zjednoczenia wszystkich Słowian pod zwierzchnictwem Rosji. Część operacyjna projektu dotyczyła z konieczności również „kwestii polskiej”. W przeciwieństwie do Słowian południowych, darzonych przez elity rosyjskie sympatią i wspieranych w ich walce o narodowe wyzwolenie, Polacy postrzegani byli jako element kulturowo obcy i politycznie niepewny (głównie za sprawą swojej, eksponowanej silnie przez dyskurs panslawistyczny, „łacińskości”), co w konsekwencji wyłączało ich z projektu, a w ostatecznym rozrachunku sytuowało po stronie cywilizacyjnego wroga (Zachodu). Jednak, zdaniem Konstantina Duszenki, ,próba wywindowania Polaków na pozycję uniwersalnego wroga Rosji i Rosjan" raczej się nie udała. W drugiej połowie XIX wieku 
miała się ona okazać nawet anachronizmem. „Zamiast mitologemy Polak-wróg w ideologii prawicy nacjonalistycznej pojawia się mitologema «Żyda», zamiast «polskiej intrygi» pojawiają się «knowania żydowskie»" (Duszenko 159). Istotnie, dyskurs rosyjski wykazuje się większą elastycznością w odniesieniu do Polski. Jego binarne uwikłania w kulturowe modele obrazowania polskiego Innego są w większym stopniu funkcjonalizowane przez dyskurs (geo)polityczny.

\section{3.}

Osobny rozdział w historii ustalania się polsko-rosyjskich klisz poznawczych zapisał XX-wieczny dyskurs propagandy państwowej. Przy czym zwłaszcza tutaj możemy dostrzec wyraźną korelację między binarnością i procesem maskowania sfery realnych odniesień wzajemnych. Skomplikowane, pełne żywych resentymentów stosunki polsko-rosyjskie pierwszej dekady PRL-u zostały na gruncie propagandy sowieckiej poddane znamiennej transformacji symbolicznej (odpowiednie wzorce retoryczne wypracowano wcześniej, w czasach wojny polsko-bolszewickiej): miejsce tradycyjnego wroga kulturowo-cywilizacyjnego (Polak łacinnik, zdrajca Słowiańszczyzny, niewdzięczny buntownik) zajął modelowany według zawężających kryteriów ekonomicznych wróg klasowy (polski obszarnik i kapitalista). Odpowiedzią po stronie polskiej było m.in. lansowanie poglądu o istnieniu postępowej, sympatyzującej ze sprawą polską przedrewolucyjnej inteligencji rosyjskiej, którą przeciwstawiano demonizowanemu aparatowi urzędniczemu i wojskowemu caratowi. Co ciekawe, dychotomia rozciągała się również na obraz Rosjan jako tzw. zwykłych ludzi. Z jednej strony są oni przedstawiani jako przyjaźni, współczujący i pokorni wobec losu, z drugiej zaś jako nieokrzesani, zacofani i irracjonalni. Zazwyczaj przy tym „zwykłego Rosjanina” przeciwstawia się przedstawicielom opresyjnej władzy (urzędnikom, politykom, wojskowym, ideologom etc.). Można się przy tym zastanawiać, czy wspomniane bieguny nie dopełniają się nawzajem, tworząc w istocie jednolity wzorzec, za sprawą zaznaczającego się w obu przypadkach czynnika obcości. Warto w tym kontekście przypomnieć, że inherentną właściwością fenomenu Rosji jako tekstu kultury - postrzeganej przez pryzmat zarówno jej politycznych praktyk, jak i sugestywnych sublimacji w literaturze i sztuce - pozostaje zasadnicza, przez samych Rosjan częstokroć wydatnie eksponowana, odmienność od reszty świata.

Wprawdzie dyskurs propagandy nie jest tekstem kultury, którego znaczenie wyczerpuje się w prostej, np. politycznej, funkcjonalności, jednak to w nim właśnie mogą ujawniać się ze szczególną wyrazistością „słabości” binarnego modelowania. Widoczne jest to $\mathrm{w}$ obszarze interferencji polsko-rosyjskich, gdzie zwraca uwagę zarówno łatwość, z jaką propaganda przyswajała zastane schematy 
projekcyjne (swój - obcy, sojusznik - wróg etc.), jak i nieszczelność stosowanych przez nią mechanizmów maskujących kłopotliwe aspekty relacyjne.

$\mathrm{Na}$ odrębną uwagę zasługuje tutaj sytuacja po roku 1945. Zasadnicza różnica między okresem PRL-u a wcześniejszymi (oświecenie, zabory, dwudziestolecie) polegała na częściowym - a do pewnego stopnia zapewne i świadomym - odsłanianiu sfery latentnej. Propaganda komunistyczna, kreując dychotomiczny obraz Rosji - tej „,naszej”, „,właściwej”, przyjaznej, sowieckiej i tej dawnej, obcej, wrażej, carskiej - odwoływała się bowiem do szeroko pojętej sfery uzasadnień. Argumentacja geopolityczna (Związek Sowiecki jako gwarant polskiego bezpieczeństwa) mieszała się tutaj z argumentacją historiozoficzną (komunizm w wersji sowieckiej jako finalizacja teleologicznie rozumianego procesu dziejowego). Chodziło o dopasowanie wizerunku rosyjskiego Innego do nowej konfiguracji państwowo-politycznej, co wymagało jednak posłużenia się bogatszym niż dotychczas zestawem narzędzi modelujących. W dzieło rekontekstualizacji owego Innego zaprzęgnięta została nie tylko machina propagandy politycznej, ale również dyskursy artystyczne, system edukacji etc. Upowszechnianie wiedzy o narodach ZSRR, względnie wszechstronna obecność kultury rosyjskiej w przestrzeni medialnej, rozwijanie sfery tzw. wymiany kulturalnej, jakkolwiek motywowane specyficzną pragmatyką i nierzadko w różnych formach kontestowane przez społeczeństwo polskie, rozszerzało mimowolnie pola kontekstualne, na których tematyzowana była Rosja. W rezultacie następowało pewnego rodzaju osłabianie binarności w polskim postrzeganiu Rosji; wytrącanie go z literaturocentrycznej ramy pojęciowej wspieranej przez synkretyczny system wartości dyskursu potocznego. Szczególnego znaczenia nabierał (obecny wprawdzie i wcześniej, np. w oświeceniu, jednak nie w wymiarze publicznym) czynnik egzystencjalno-polityczny: Rosja jako fundamentalny układ odniesienia dla rozważań o polskim bezpieczeństwie, a nawet o polskiej zdolności do przetrwania, tak w sensie państwowym, jak i w sensie biologicznym (ocalenie przed zagładą z rąk nazistów, zagrożenie wynikające z konfliktu zimnowojennego). Peerelowski dyskurs propagandy (nie jest to, rzecz jasna, określenie o charakterze genologicznym: odnosi się ono do różnych pod względem formy i zasięgu sposobów tematyzowania Rosji i stosunków polsko-rosyjskich; wspólnym mianownikiem pozostaje tu oficjalny, publiczny wymiar tego dyskursu) okazał się z kulturowego punktu widzenia formą racjonalizacji, być może nieco paradoksalnej, polskiego spojrzenia na Rosję. Odsłaniał, choć z różnych powodów nieskutecznie, anachroniczność tradycyjnej binaryzacji, która umieszczała Rosję i rosyjskość po stronie emotum, polskie położenie w świecie i polską świadomość definiując w kategoriach ratio. Dyskontynuacja tego kierunku, jaka nastąpiła po 1989 roku, skutkująca radykalną redukcją tematyki rosyjskiej (z wyłączeniem polityki międzynarodowej Federacji Rosyjskiej) w szerszej przestrzeni dyskursywnej, pokazuje m.in. brak jego instytucjonalnego zakorzenienia. 


\section{4.}

Jak już zostało powiedziane, kluczową rolę w utwierdzaniu prymatu kulturalistycznego sposobu modelowania obrazu Rosji i Rosjan odegrała formacja literaturocentryczna, genetycznie związana z romantyzmem jako prądem kulturowym, lecz uobecniająca się szeroko w myśleniu potocznym. Względnie łatwe przenikanie postaw elitarnych do sfery odczuć i wyobrażeń zbiorowych ułatwiał niewątpliwie fakt, iż romantyzm odwoływał się do wspólnych, ponadklasowych doświadczeń historycznych Polaków oraz do głęboko zinternalizowanych w wiekach wcześniejszych form stygmatyzacji wschodniego Innego jako schizmatyka i barbarzyńcy, czego odpowiednikiem po stronie rosyjskiej były analogiczne projekcje polskiej podstępności i zaborczości (dymitriady) oraz polskiego jezuityzmu. Uprawiana przez romantyków poetyka różnicy (My - Oni) swoją społeczną nośność zawdzięczała również temu, że umiejętnie kanalizowała - poprzez osadzenie ich w binarnej strukturze wyobrażeniowej - społeczne lęki i frustracje związane z carskim imperium. Dawał im wyraz Zygmunt Krasiński, gdy pisał, że „Rosja jest wytworem i zbiorem pierwiastków najbardziej złowrogich i najbardziej rozkładowych, jakie są w historii" (Krasiński, źródło elektroniczne). Jednocześnie u tego samego autora natrafiamy na wypowiedź, która rzuca ciekawe światło na sposób „przepracowywania” lęku przed rosyjską zaborczością: „Jeżeli Rosja ma przestać być plagą, gotową zawsze spaść na Kościół, na cywilizację, na świat, to jest na to jeden tylko sposób, doprowadzić ją do zupełnej niemocy. Wszelki pokój, zawarty przed tym ostatecznym rezultatem, pogorszy tylko sytuację i popchnie nieprzyjaciela do nowych i straszniejszych wysiłków" (Krasiński, źródło elektroniczne). Utrwalony za sprawą sarmackiej autoafirmacji (kulminującej w koncepcie Przedmurza) kod binarny oddzielający cywilizację od barbarii, polską łacińskość od moskiewskiej schizmatyckości, został „wzmocniony” przez romantyczną racjonalizację lęku i traumy porażki. Unicestwienie rosyjskiej potęgi, które postuluje autor Nie-Boskiej komedii, może jawić się jako wyrozumowana konieczność, wynikająca z obiektywnych przesłanek. W ogólniejszym planie możemy w tym jednak widzieć radykalną identyfikację z ratio dla tym silniejszego zdystansowania się od rosyjskiego emotum. Tak rozumiane ratio jest w pierwszym rzędzie funkcją lęku.

Wiodło to do sięgnięcia po imagologicznie najbardziej sugestywne i społecznie nośne - głównie za sprawą Dziadów i Kordiana - narzędzie „pogłębionej” binaryzacji, jakim stała się demonizacja Rosji. Sięgnijmy po znamienne przykłady. W wykładach o literaturze słowiańskiej Adam Mickiewicz znaczny potencjał swojej obrazotwórczej magii spożytkowuje we fragmentach poświęconych uwypukleniu różnicy między Polską i Rosją. W jednym z najbardziej ekspresywnych odwołuje się autor Drogi do Rosji do języka uruchamiającego skojarzenia z de- 
monologicznymi sferami wyobraźni ludowej, w czym niewątpliwie wyraża się jego pierwotna siła stygmatyzująca. Interesujący krąg dociekań wyznaczają rozważania Witolda Klingera (1957) na temat związków Mickiewiczowskiej Drogi do Rosji z pierwszym Listem filozoficznym Czaadajewa.

Lud Wielkiej Rosyi odznacza się pomiędzy innemi szczepami rodu słowiańskiego. Wysoki wzrostem, silny, barczysty, celuje bystrością umysłu, jest może pod tym względem najpierwszym w Europie; ale serce ma nieczułe i duszę zimną: nie lubi muzyki i śpiewu jak Słowianie południowi; w oczach nosi jakiś wyraz szczególniejszy. Patrząc w te oczy podobne do kropel zlodowaciałych, widzi się cóś strasznego, cóś na kształt głębi bez dna: światło odbija się od nich, ale nie płonie w soczewce. Jest to wzrok jasny, przeszywający, wzrok nie człowieka, ani zwierzęcia, ale raczej owadu. Żeby mieć wyobrażenie o nim, trzeba wziąść pod szkło powiększające jaki owad, i przyglądać się jego oczom nieruchomym, przezroczystym, przenikliwym i zimnym (Mickiewicz 67).

Z kolei w mniej znanym poemacie Słowackiego Poema Piasta Dantyszka herbu Leliwa o piekle spotykamy się z charakterystyczną „infernalizacją” wątku rosyjskiego, odwołującą się do określonego wizerunku moskiewskiego systemu władzy. Poeta, przywołując postać Piotra Wielkiego, czyni zeń element nośny architektury piekielnej:

Wieża piekielna oparta na Carze

Na jednym trupie, jak na zgniłym palu

Cała się trzęsie wisząc na moskalu.

A nie dziw się sile trupiej belki

Bo to w osobie piekielnej Piotr Wielki.

Siedzi pod wieżą, a na niego z cebra

Jakieś straszydło okropne, puchacze

Wylewa ciepłą krew ludu i płacze

I oczerwienia mu łeb, piersi, żebra (Słowacki w. 579-587).

\section{5.}

Binarny charakter polsko-rosyjskich przeciwstawień, będący efektem pewnego symbolicznego nadmiaru w uzewnętrznianiu lęku i irytacji (generowanego w dużej mierze przez literaturocentryczny model obu kultur), bardzo utrudnia oczyszczenie pola wzajemnej komunikacji. Przesłania również dialektyczny, symboliczno-geopolityczny wymiar polsko-rosyjskich odniesień.

Niezależnie od procesów zachodzących w sferze kultury piśmienniczej niemała część Polaków dostrzegła, że w miejscu zajmowanym przez statycznego sowieckiego molocha, poruszającego się - z rosnącym trudem - przy użyciu dźwigni groteskowej propagandy, zaczęła się wyłaniać coraz bardziej skomplikowana, wielowymiarowa i interesująca rzeczywistość społeczna, będąca jedyną w swoim 
rodzaju mieszaniną nowoczesności i obskurantyzmu, dynamizmu i stagnacji, bogactwa i biedy. Niestety, wydaje się, że analogiczna tendencja występuje po stronie rosyjskiej w nieporównanie mniejszej skali.

Polsko-rosyjskie postrzeganie wzajemne wymaga daleko idącego urealnienia. Oczywiście, można sobie wyobrazić, że nie przyniosłoby ono rezultatów odbiegających zasadniczo od narracyjno-imagologicznego status quo. Mogłoby jednak sprzyjać uwolnieniu od ograniczających mocy binarności, nie zabezpieczając wszelako przed innego rodzaju uproszczeniami. Świadomość pozostawania w sieci określonych kulturowych kodów i uwikłań nie jest równoznaczna z uznaniem zależności od jednoczynnikowego determinizmu; przeciwnie - odsłania perspektywę, w której to poszczególne wspólnoty dialogu kształtują percepcyjne ramy wzajemnych odniesień, nie zaś fatalistycznie rozumiana historia czy politycznie konceptualizowana geografia.

\section{Bibliografia}

Bakuła, Bogusław. „Rosyjska wewnętrzna kolonizacja (Alexander Etkind, Internal Colonization. Russia's Imperial Experience. Cambridge, Polity Press 2011, s. 289)". Porównania, 15, 2014, s. 341-356.

Bartosiak, Jacek. Rzeczpospolita - między lądem a morzem. O wojnie i pokoju. Warszawa, Zona Zero, 2018.

Czapliński, Przemysław. Poruszona mapa. Wyobraźnia geograficzno-kulturowa polskiej literatury przełomu XX i XXI wieku. Kraków, Wydawnictwo Literackie, 2017.

Duszenko, Konstantin. „Polak i Polka w oczach Rosjan”. Przeł. Andrzej Branny. Narody i stereotypy. Red. Teresa Walas. Kraków, Międzynarodowe Centrum Kultury, 1995, s. 158-164.

Gołębiewska, Maria. „Naturalizacja mitu według Rolanda Barthes’a”. Imperium Rolanda Barthes 'a . Red. Anna Grzegorczyk, Agnieszka Kaczmarek, Katarzyna Machtyl. Poznań, Wydawnictwo Naukowe UAM, 2016, s. 81-93.

Janion, Maria. Niesamowita Stowiańszczyzna. Fantazmaty literatury. Kraków, Wydawnictwo Literackie, 2007.

Jastrzębska, Joanna. „Kolonizacja? Rekolonizacja? Polonizacja? czyli Rosja po polsku”. Refleksje. Pismo naukowe studentów i doktorantów WNPiD UAM, 8, 2013, s. 63-78.

Kępiński, Andrzej. „Geneza i funkcjonowanie negatywnego stereotypu Rosji i Rosjanina”. Narody i stereotypy. Red. Teresa Walas. Kraków, Międzynarodowe Centrum Kultury, 1995, s. 153-157.

Klinger, Witold. „Elementy rosyjskie w Mickiewicza Drodze do Rosji”. Pamiętnik Literacki, 3 , 1957, s. 160-177.

Krasiński, Zygmunt. Memoriat dla Napoleona III. Web. 10.10.2019. https://polskietradycje.pl/ artykuly/widok/279.

Lipatow, Aleksander. „Rosja i Polska - «domowy spór» Słowian czy konflikt mentalności?”. Napis, 6, 2000, s. 245-255. Web. 09.10.2019. https://rcin.org.pl/dlibra/publication/69836/ edition $/ 56827 /$ content.

Lipatow, Aleksander. „Stereotypy percepcji narodowej albo dlaczego Rosjanie i Polacy nawzajem się nie rozumieją”. Skomplikowane stosunki Polaków i Rosjan. Red. Michał Dobroczyński, Joanna Marszałek-Kawa. Toruń, Wydawnictwo Adam Marszałek, 2005, s. 154-169. 
[Mickiewicz, Adam]. Literatura stowiańska wykładana $w$ Kolegium francuzkiem przez Adama Mickiewicza. Ttumaczenie Felixa Wrotnowskiego. Rok drugi, 1841-1842. Web. 17.12.2019. https://archive.org/stream/literaturasowia02mickgoog/literaturasowia02mickgoog_djvu.txt.

Morawiec, Edmund. Wybrane filozoficzne koncepcje rozumu ludzkiego i racjonalność. Warszawa, Wydawnictwo Liberi Libri, 2014.

Nowak, Andrzej. Metamorfozy Imperium Rosyjskiego 1721-1921. Geopolityka, ody i narody. Kraków, Wydawnictwo Literackie, 2018.

Skórczewski, Dariusz. „Dlaczego Polska powinna upomnieć się o swoją postkolonialność”. Znak, 628, 2007. Web. 15.12.2019. https://www.znak.org.pl/files/Skorczewski.pdf.

Skórczewski, Dariusz. „Hegemon jako idol: propozycja teoretyczna”. Porównania, 19, 2016, s. 58-69.

Skrzypek, Andrzej. Polska-Rosja - stereotypy. Web. 16.09.2019. https://www.wbc.poznan.pl/dlibra/docmetadata?showContent $=$ true $\&$ id $=39758$.

Słowacki, Juliusz. Poema Piasta Dantyszka herbu Leliwa o piekle. Web. 16.11.2019. https://pl.wikisource.org/wiki/Poema_Piasta_Dantyszka_herbu_Leliwa_o_piekle.

Thompson, Ewa. Trubadurzy imperium. Literatura rosyjska i kolonializm. Przeł. Anna Sierszulska. Kraków, Universitas, 2000.

Thompson, Ewa. Zrozumieć Rosję. Święte szaleństwo w kulturze rosyjskiej. Przeł. Eliza Litak. Warszawa, Teologia Polityczna, 2019.

Ziemkiewicz, Rafał. „W co gra Putin?”. Rzeczpospolita, 29.01.2011. Web. 09.09.2019. https://www. rp.pl/artykul/601920-Ziemkiewicz--W-co-gra-Putin-.html. 